Reprod. Nutr. Dévelop., 1980, 20 (3 B), 881-889.

\title{
Early mother-child contact and nursing
}

\author{
par S. G. CARLSSON, K. LARSSON, J. SCHALLER \\ Dept. of Psychology, Unit of Psychology, \\ Univ. of Göteborg, Fack, S-400 20 Göteborg, Sweden.
}

Summary. Mothers with extended body contact with their babies immediately after delivery showed more tactual contacts with their newborns when observed during the first week after parturition than mothers who had been exposed to ordinary hospital routine. These group differences could not be observed five weeks later. No other types of behavior seemed to be affected by extended body contact.

\section{Introduction.}

Animal studies have revealed complex processes of interaction between the mother and her young. As has been shown by Rosenblatt and his associates for rats and cats (Rosenblatt, 1971 ; Schneirla ef al., 1963) and by Noirot (1972) for mice and hamsters, the behavior of the mother is adapted to the needs and behavioral capacities of the young. In humans, relatively little is known about the early post-natal development of the mother-child relationship. Psychologists have mainly been interested in the later stages of this development and ethologists have only recently begun to apply their observational techniques to humans. An important role of close mother-child interaction is, however, suggested by Klaus who observed that mothers given body contact immediately after delivery tended to behave in a more affectionate way towards their babies one month later (Klaus et al., 1972).

Inspired by the work of Klaus, we have studied the effects of extended body contact immediately after delivery on the mother's nursing behavior. The study was initiated when a new ward routine was planned in one of the two obstetric wards at the Mölndal Hospital in Sweden. In an attempt to evaluate whether additional contact between mother and child during the first days post-partum reinforced the effect of immediate contact after delivery, we also studied mothers in wards where the routines permitted more frequent interaction with the baby. Our study can be partly regarded as a replication of the work of Klaus ef al. (1972), though extended to a more representative population of Western mothers. Our design also permitted the investigation of the effects of immediate post-partum contact per se. 


\section{Subjects and procedures.}

In Sweden all hospital care is free. Each mother is assigned to a public hospital and remains in contact with it during the entire period of pregnancy. The subjects in this study were 62, randomly selected, primiparious mothers, about 25 years old, living under socially stable conditions, with no complications during delivery. The subjects were unaware of the purpose of the study. Prior to delivery, the mothers were randomly assigned to one of three experimental groups:

Group A. - Extended contact, new routine.

Group B. - Extended contact, old routine.

Group C. - Limited contact, old routine.

Limited contact means that the mother was allowed to hold her baby for a maximum of $5 \mathrm{~min}$ immediately after delivery. The baby was then taken away, washed and placed in a separate crib by the mother's bed, where it remained until moved to the ward.

Extended confact means that the mother was allowed to keep her naked baby in her bed for 1-2 hrs immediately after delivery. The baby was placed on the mother's body in nursing position, or at her side with its face touching the mother's breast. The baby

TABLE 1

Behavior categories used in observation

No. Description

\section{Contact behavior}

1 Mother rubs or pats the child to make it burp.

2 Mother kisses the child or brings if into face-to-face contact.

3 Mother rocks infant.

4 Mother touches infant's bare skin either before nursing has started or during nursing when infant has the nipple in its mouth but does not suck.

5 Mother touches infant's bare skin when it sucks or when it does not have the nipple in its mouth.

Mother pats clothed parts of infant.

Mother adjusts infant's clothing.

Mother talks to infant.

"En face ". Mother aligns her face in the same vertical plane of rotation as the infant's (Robson, 1967).

Mother smiles at infant.

Mother holds infant with both arms in an almost horizontal position.

Mother keeps infant against her shoulder or vertically against her chest.

Mother keeps infant in hands ; infant not touching mother's chest.

Mother keeps infant lying in her lap.

Behavior not implying contact with baby

15 Mother talks to someone other than infant.

16 Mother looks away from infant.

17 No physical contact between mother and infant.

18 Infant lying beside mother, both in horizontal position. 
was thereafter taken away, washed and placed in a separate crib by the mother's bed until moved to the ward.

Old routine essentially means that the main concern of the nurse was nursing the newborn.

New routine means that the nurse was mainly concerned with advising and supporting the mothers.

The subjects were observed when breast-feeding or bottle-feeding on the 2 nd, 4 th and 42 nd days post-partum. All the mothers breast-fed during the 2 nd and 4 th days, and only a minor portion had begun bottle-feeding before the 42 nd day. The behavior indicated in table 1 was recorded during consective 15-sec periods. The observation started when the baby first took the nipple in its mouth and ended as soon as 2 min had passed since the last contact between the nipple and the baby's mouth. During each 15-sec period, the observer recorded the behavior components present. Only one mark was noted for a given behavior, regardless of its frequency within the period. Naturally, the duration of feeding varied both between and within the mothers. The behavior frequencies were corrected for this variation. The corrected frequencies corresponded to a feeding time of $25 \mathrm{~min}$.

\section{Short-term effects of extended post-partum contact.}

During the first observations of nursing on days 2 and 4, all the mother breastfed their newborns. Group A included 20 mothers and Group C 22. Table 2 shows the behavior displayed by the mothers when feeding. There were no group differences in the duration of feeding. However, there were differences between groups in the quality of interaction between mother and child. The mothers in Croup A and B showed more contact behavior (rubbing and patting the child, rocking infant, touching infant's bare skin and clothes, holding infant in arms and/or againts body, infant lying in lap) and less non-contact behavior (no physical contact between mother and infant ; infant lying aside in horizontal position) than did mothers in Group C. Although these differences could be secondary to differences in the distribution of sucking vs.

TABLE 2

Coefficients of correlation indicating the stability of the mother's behavior at three different observations

\begin{tabular}{|c|c|c|c|}
\hline \multirow{2}{*}{ Behavior class } & \multicolumn{3}{|c|}{ Days compared } \\
\hline & $2 n d-4 t h$ & 2nd-42nd & $4 t h-42 n d$ \\
\hline $\begin{array}{l}\text { Proximal-« clothes } » \ldots \ldots \ldots \\
\text { Proximal-« skin-to-skin }{ } \ldots \ldots \\
\text { Proximo-distal } \ldots \ldots \ldots \ldots \\
\text { Sum of contact behavior } \ldots \ldots \ldots\end{array}$ & $\begin{array}{l}0.63 * * * \\
0.47 * * * \\
0.33 * \\
0.47 * * *\end{array}$ & $\begin{array}{l}0.19 \\
0.28 * \\
0.41 * * \\
0.47 * * *\end{array}$ & $\begin{array}{l}0.17 \\
0.37 * * \\
0.37 * * \\
0.42 * *\end{array}$ \\
\hline
\end{tabular}

\footnotetext{
$* P<0.05$.

** $P<0.01$.

*** $\mathrm{p}<0.001$.
} 
non-sucking, no differences in the amount of sucking were found between the three groups. The differences in the ward routine were not reflected in the mothers' nursing behavior ; no differences were found between Groups A and B.

The results show that tactile contact between mother and child, for a period of time not exceeding $2 \mathrm{hrs}$ immediately after delivery, affected nursing behavior during the first four post-partum days. The immediate separation, often included in Western obstetric routines, obviously reduced, at least temporarily, the affective components in the mother-child interaction. A ward routine including more extensive contact between mother and child did not further increase the effects of contact immediately after delivery.

\section{Effects of extended post-partum contact on the mother's behavior six weeks after delivery.}

This part of our study included 50 mothers from our study on nursing the first week after delivery. Twelve mothers from the original sample were not available for this observation. Groups A and B included 17 pairs each and Group $C$ included 16 pairs.

No group differences were found in any of the 18 behavioral categories. Those categories were also grouped into various classes, such as contact vs. non-contact behavior. However, none of the further testing revealed any significant group differences.

Apart from the behavioral observations, we interviewed the mother regarding various aspects of the mother-infant relationship. She was asked about her reactions to the ward routines, the post-partum contact with the midwife, breast-feeding, nursing and the role of the father in the care of the baby. She was also questioned about her plan for working and for care. Even that approach failed to reveal any group differences.

\section{Tactual and non-tactual contact behavior in human nursing.}

After discussing the overall results of our experimental method, we now turn to some qualitative aspects of the mother's feeding behavior. In a separate analysis, we evaluated the role of tactual contact in the interaction of the mother and her newborn during the first six weeks after delivery. For that analysis, the behavior patterns observed were classified according to whether the contact was exclusively physical (proximal : mother rubs or pats the child to make it burp; mother kisses the child or brings it into face-to-face contact; mother touches the infant's bare skin ; mother pats clothed parts of infant; mother adjusts infant's clothing) or whether it also involved distal contact (mother talks to the infant ; "en face » - mother aligns her face in the same vertical plane of rotation as infant's face ; mother smiles at infant). The particular ward routine to which the mother had been exposed was not considered. All the 46 pairs participating in all three observations were included in this analysis.

Figure 1 shows the frequencies of the various contact behaviors exhibited by the mother at each observation. During the 2 nd and 4 th day, proximal contact dominated ; thereafter it gave way to proximo-distal contact. Only small changes were seen in the 


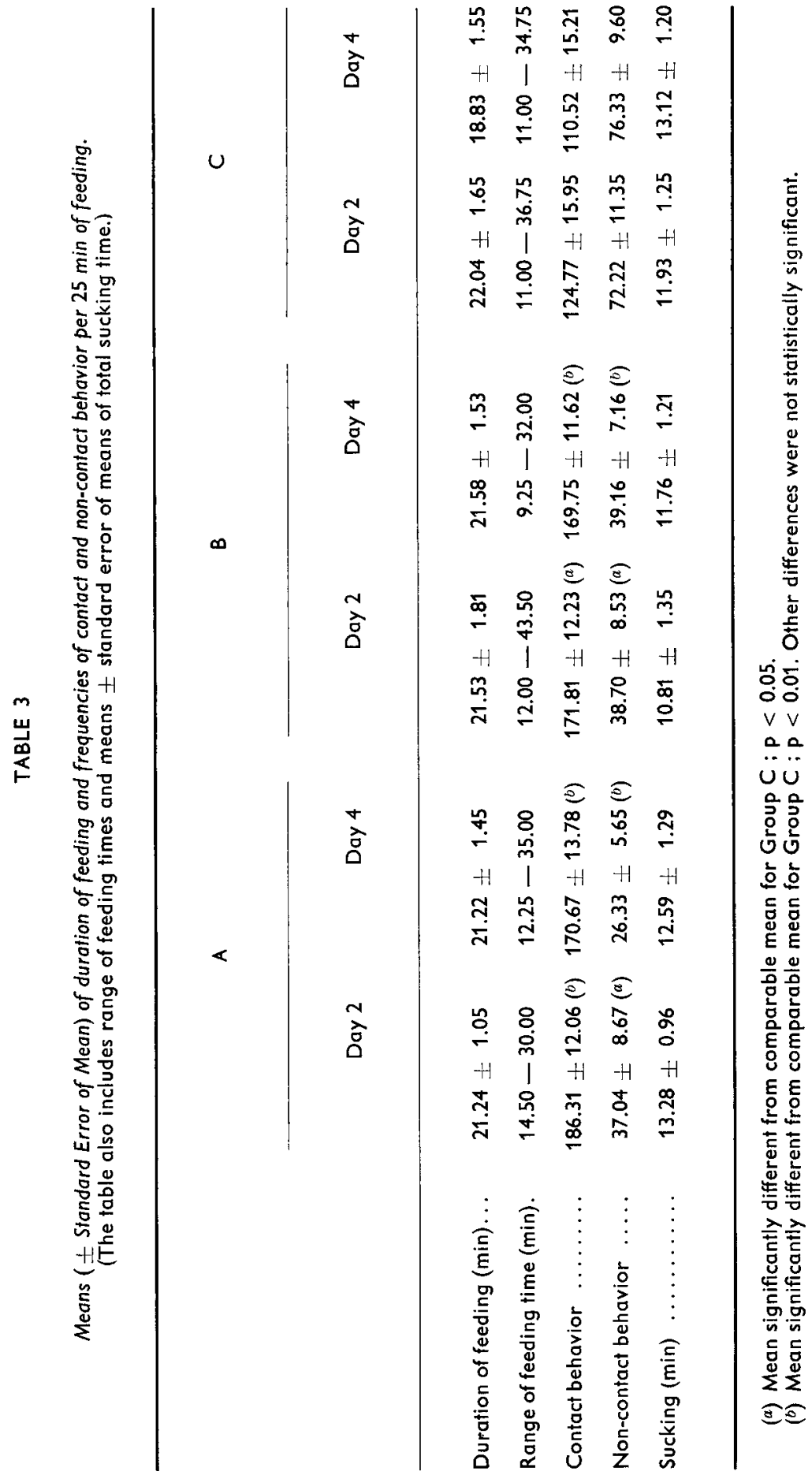


proportion of cloth-contacts (2nd-4th day, $\mathrm{p}<0.05 ; 2$ nd-42nd day, NS ; 4th-42nd day, NS) but the number of skin-to-skin contacts showed a highly significant decrease (here, we used the two-tailed t-test : 2 nd-4th days, NS ; 2 nd-42nd days, $p<0.001$; 4th-42nd day, $p<0.001$ ), while the proximal contacts decreased; there was a steady increase of proximodistal contacts. On day 42 , the proximo-distal contacts represented the major proportion of all contacts. It should be observed that the decrease in proximal contacts was much more marked than the increase in proximo-distal confacts.

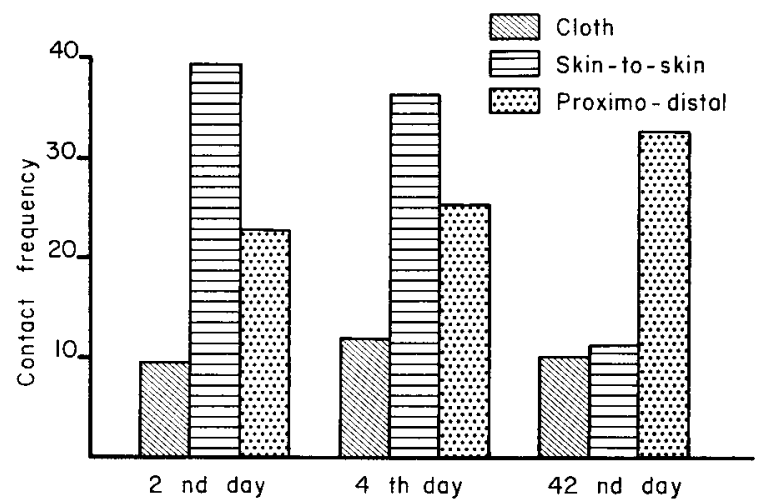

FIG. 1. - Frequencies of various contact behaviors at the 2 nd, 4 th and 42 nd days post-partum.

The mothers showed a remarkable stability in their behavior. Table 3 shows coefficients of correlation between the behavior exhibited on different occasions. An exception was the cloth contact behavior where correlations between the Ist and 6th week were not statistically confirmed. Those behavior patterns might be a maternal reaction to the hospital routine rather than a genuine expression of mother-child interaction.

The results of this analysis indicated the great importance of tactual contact between the mother and her newborn during the period of time immediately following delivery. In the following weeks, the importance of tactual contacts decreased, giving way to other means of communication.

\section{Comments on the nature of the effects of extended post-partum body contact.}

Our analysis, so far, has indicated the effects of extended body contact after delivery on the interaction between the mother and her newborn, but has given little insight into the nature of the effects obtained. Speculating that extended bcdy contact may promote similar contacts later on, we submitted our data to another analysis.

The subjects in this analysis were all the 46 mothers participating in all three observations. Since no group differences according to ward routine were observed, Groups $A$ and $B$ were combined. The observations from the 2 nd and 4 th days were combined (《Ist week ») and compared with the day 42 ( 6 th week ») observations. Only behavior categories representing proximal and proximo-distal contacts were included. 
Figure 2 shows the results of this analysis. A highly significant difference was found in the mean number of proximal contacts during the 1 st week in Group $A+B$ as compared to Group $C(P<0.01)$. This difference had completely disappeared at the 6 th week. The mean number of proximal contacts had markedly decreased for both groups. No significant group differences were found in the number of proximo-distal contacts during the 1 st to the 6 th week.

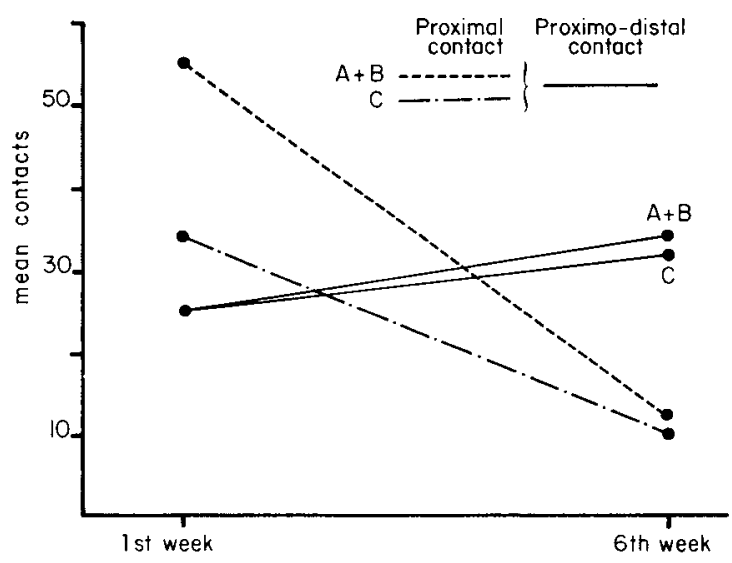

FIG. 2. - Mean proximal and proximo-distal contact behavior showed by the mother when nursing her newborn in the 1 st and 6 th weeks after delivery.

The results of this analysis showed that extended body contact after delivery exclusively influenced aspects of the mother's nursing behavior involving proximal contacts. The effects of extended body contact upon proximal contact behavior disappeared within 6 weeks.

\section{Conclusions.}

Our results as well as those reported by Klaus et al. (1972) and by de Chateau and Wiberg (1977a) indicated the effects of post-partum contact upon maternal nursing behavior during the first week after delivery. However, the magnitude of these effects should not be overestimated. Indeed, as compared to the effects of mother-young separation in some animal species, those reported in the human are marginal. Klaus et al. (1972) reported statistically significant group differences in only 2 out of 25 observational categories (fondling and en face) one month after delivery. The group differences in 3 out of 35 observational categories, reported by de Chateau and Wiberg $(1977 a)$, were mother leaning on elbow, mother sitting up, mother holding infant. As indicated by the authors, two of these categories were mutually exclusive, and only one behavior (holding infant) denoted affectionate relationship.

We observed no effects of extended body contact at 6 weeks post-partum. This is surprising in view of several reports indicating effects lasting over months and years, increasing in importance over time rather than decreasing, and encompassing a broadening range of behavior patterns (Kennel et al., 1974 ; de Chateau, 1977b) ; 
Ringler et al., 1975). At a pediatric examination test performed one year after delivery, Kennel et al. (1974) found that mothers, who had been allowed extended body contact post-partum, tended to avoid separation from their babies and showed more affectionate behavior toward their children. Further, the babies of these mothers showed higher developmental scores. Examining the verbal behavior of the same infants, Ringler et al. (1975) found, at 2 years, that infants in the extended body contact group showed group differences in 5 different aspects of verbal behavior out of the 7 aspects studied. Strangely enough, at a similar examination at 1 year of age, the group differences were reversed in 4 of these categories. Observing 3-month old babies in a situation involving free play, de Chateau ef $a l$. (1977b) found 5 significant differences among 61 behavioral calegories analyzed. It should be noted that none of these categories were identical for the two sexes. More pronounced group differences were found immediately (de Chateav, 1978) and at 3 years (de Chateau and Wiberg, 1978) post-partum.

As opposed to the animal studies, where an immediate effect of importance for survival is observed, some of the human studies seem to demonstrate more of a sleeper effect. Other interpretations should, however, also be considered. One possibility is that the effects observed merely represent statistical artifacts. When the reliability of the data collection is low, the probability of incidental differences between identical groups or subgroups (for instance sex groups) increases, as does the probability of changes in the pattern of differences when the same groups are restudied. A further possibility is that the groups become different because of a Hawthorn effect : with time, the mothers in the group receiving extended body contact post partum are influenced by various expectations from the rather extensive attention paid to these problems in the mass media. It is felt that until these latter two interpretations have been excluded, the hypotheses of a sleeper effect of extended body contact is not acceptable.

It may be speculated that at an early stage of human evolution, the factors contributing to a maximal physical contact between mother and child in early life had an important value. For modern man, the situation is different; continuous body contact is no longer necessary for survival. Even though extended body contact may have only limited significance for the optimal development of the child in a modern society, one should not overlook the value of a positive emotional experience of such a contact. On the other hand, to be a good mother, early body contact should not be considered à « must ».

Colloque " La relation parentale » Nouzilly, France, juin 1979.

Résumé. Des mères ayant eu un contact corporel important avec leur bébé immédiatement après l'accouchement présentent plus de contacts tactiles avec leur enfant lorsqu'elles sont observées lors de la première semaine après la naissance, par rapport à des mères ayant subi le traitement de routine de l'hôpital. De telles différences ne peuvent plus être observées 5 semaines plus tard. Aucun autre type de comportement ne semble affecté par l'importance du contact corporel précoce. 


\section{References}

CARLSSON S. G., FAGERMAN N., HORNEMAN G., HWANG P., LARSSON K., RÖDHOLM M., SCHALLER J., DANIELSSON B., GUNDEWALL C., 1978. Effects of various amounts of contact between mother and child on the mother's nursing behavior. Develop. Psychobiol., 11, 143-150.

CARLSSON S. G., FAGERBERG J., HORNEMAN G., HWANG C. P., LARSSON K., RÖDHOLM M., SCHALLER J., DANIELSSON B., GUNDEWALL C., 1979. Effects of various amounts of contact between mother and child on the mother's nursing behavior : A follow-up study. Infant Behav. Develop., 2, 209-214.

DE CHATEAU P., WIBERG B., 1977a. Long-term effect on mother-infant behavior of extra contact during the first hour post-partum. I. First observation at 36 hours. Acta paediatr. scand., 66, 137-143.

DE CHATEAU P., WIBERG B., 1977b. Long-term effect on mother-infant behavior of extra contact during the first hour post-partum. II. A follow-up at three months. Acta paediatr. scand., 66, 145151.

DE CHATEAU P., 1978. Parent-infant relationship after immediate post-parfum contact. Proc. 2nd int. Congr. Child abuse and neglect. London.

DE CHATEAU P., WIBERG B., 1978. Tidig postnatal föräldrar-barn kontakt : 3 ars uppföljning. Hygiena, 87, nr 3, Läkarsällskapets riksstämma 29/11-2/12 1978. Sammanfattningar.

KENNEL J. H., JERAULD R., WOLFE H., CHESLER D., KREGERS N. C., MCALPINE W., STEFFA M. KLAUS M. H., 1974. Maternal behavior one year after early and extended post-partum contact. Develop. Med. Child Neurol., 16, 172-179.

KLAUS M. H., JERAULD R., KREGERS C., MCALPINE W., STEFFA M., KENNEL J. H., 1972. Maternal attachment ; importance of the first post-partum days. New Engl. J. Med., 286, 460-463.

NOIROT E., 1972. The onset of maternal behavior in rats, hamsters, and mice : A selective review. In LEHRMAN D. L., HINDE R. A., SCHAU E. Advances in the study of behavior, Vol. 4, 107-145. Acad. Press, New York.

RINGLER N. M., KENNEL J. H., JARVELLA R., NAVOJOSKY B. J., KLAUS M. H., 1975. Mother-tochild speech at 2 years, effects of early postnatal contact. Behov. Pediatr. 86, 141-144.

ROBSON K., 1967. The role of eye-to-eye contact in maternal-infant attachment. J. Child Psychol. Psychiatry, 8, 13-25.

ROSENBLATT J.-S., 1971. Views on the onset and maintenance of maternal behavior in the rat, 489-515. In ARONSON L., TOBACH E., LEHRMAN D., ROSENBLATT J. Development and evaluation of behavior, Freeman \& Co, San Francisco.

SCHALLER J., CARLSSON S., LARSSON K., 1980. Effects of extended post-parfum mother-child contact on the mother's behavior during nursing. Infont Develop. Behav. (In press).

SCHNEIRLA T. S., ROSENBLATT S. S., TOBACH E., 1963. Maternal behavior in the cat, 122-168. In RHEINGOLD H. L., Maternal behavior in mammals, Wiley, \& Sons, New York. 